1990 the Summer Institute will be located in Atlanta, Georgia. A consortium consisting of Spelman College, Morehouse College, Georgia State University and Emory University will be the new Institute sponsors. The Ford Foundation will provide partial support, and the Association is seeking additional funding from other sources.

\section{Council Revises Association's Nondiscrimination Statement}

The APSA Council voted to revise the Association's nondiscrimination statement at its August 30, 1989 meeting. The Council acted to reflect the language and definitions of the Americans with Disabilities Act of 1989. The act extends the nondiscrimination in the workplace protection to a broader range of physical and psychological disability sufferers, including individuals with AIDS or with HIV infection.

The Council's new statement reads: "It is Association policy to urge that educational institutions not discriminate against employees or applicants because of sexual orientation, marital status, physical handicap, or disability."

\section{Council Appoints Search Committee for APSR Managing Editor}

In July 1991 APSR Managing Editor Samuel C. Patterson's six-year term will end. The Council has appointed a search committee to work with APSA President Judith Shklar to identify Patterson's successor. The members of the ad hoc search committee are:

Richard Fenno, University of Rochester (Chair) Lucius Barker, Washington University Alexander George, Stanford University Virginia Gray, University of Minnesota

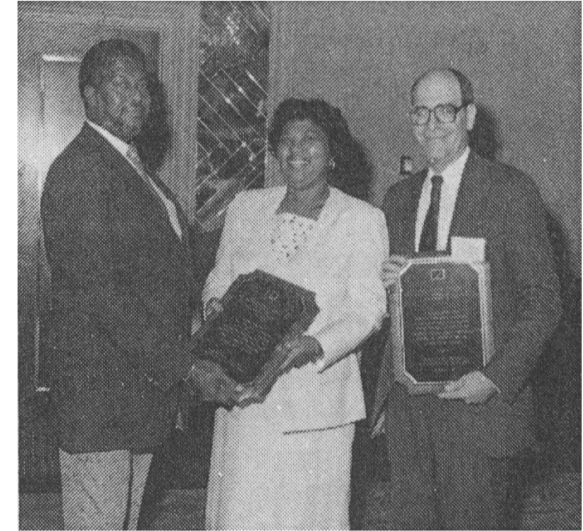

Mitchell Rice, Chair, APSA Committee on the Status of Blacks, honors Jewel Prestage and Peter Zwick, co-directors of the APSA Summer Institute in Political Science for Black Students.

Robert Jervis, Columbia University

Peter Lange, Duke University

Samuel C. Patterson, Ohio State University Judith Shklar, Harvard University (Ex Officio)

The Council will elect the next editor at its August 29, 1990, meeting after learning of the Search Committee's deliberations and hearing the recommendations of the president.

Members are encouraged to send suggestions to the Search Committee at the APSA National Office by December 15 , 1989.

\section{Travel Grants for Foreign Program Participants}

Building upon the experience of hosting the IPSA World Congress, the Association offered travel grants to several foreign scholars participating in the 1989 meeting. The funds were made available from the Ford Foundation and the German Marshall Fund of the United States.

Those who received support included: 


\section{Ford Foundation Grantees}

Caridad Inda, Cirimex, Mexico

Alfredo Rehren, Universidad de Chile, Chile

Li Fang, Chinese Academy of Social Sciences, People's Republic of China

Wang Hu, People's Republic of China

Douja Turki, University of Tunis, Tunisia

\section{German Marshall Fund Grantees}

Maurice Goldsmith, University of Essex, England

Paul Lewis, The Open University, England

Dieter $H$. Bingen, Bundesinstitut Ost, West Germany

\section{Foreign Students Attend 1989 \\ APSA Meeting with Grant Support}

Through funds provided by the Institute for International Education and the Asia Foundation, 27 foreign graduate students studying political science in the United States were given grants to help pay for their travel expenses to the 1989 APSA Annual Meeting. Of the 27 awards, 13 were funded by the Institute for International Education, and 14 were funded by the Asia Foundation.

Students from 12 countries were among the grantees. The country distribution of the awards included: Peru (1), Nigeria (2), India (2), Canada (4), Australia (1), Iran (1), Germany (1), Sudan (1), Indonesia (1), Taiwan (3), People's Republic of China (5), and Korea (5).

Listed below are recipients with their country of origin and current institution.

\section{IIE Travel Grantees}

Carlos Parodi, Peru; University of Pittsburgh

E. Victor Aikhiobare, Nigeria; Texas Tech University

Shrikant Dash, India; University of Rochester

Christian Georgen, Germany; SUNY, Stony Brook

Thomas W. Heilke, Canada; Duke University

Geoffrey B. Levey, Australia; Brown University

Mustafa M. Mustafa, Sudan; Florida State University

Daniel Marien, Canada; New School for Social Research
Antonia Maioni, Canada; Northwestern University

Jeffrey lan Ross, Canada; University of Colorado, Boulder

Yasmin Lodi, India; Purdue University

Mohammad Shirkhani, Iran; University of Idaho

Godwin Okonkwo Okafor, Nigeria; Southern Illinois University

\section{Asia Foundation Travel Grantees}

Bahtiar Effendy, Indonesia; Ohio State University

Huo-Yan Shyu, Taiwan; Florida State University Kao-cherng Wang, Taiwan; University of Pennsylvania

Melissa Fang-yuan Yu, Taiwan; University of Maryland

Jason Q. Qian, China; University of Maryland Suisheng Zhao, China; University of California, San Diego

Jianhua Zhu, China; Indiana University

Yang Zhong, China; University of Kentucky

Yan Sun, China; Johns Hopkins University

Kisuk Cho, Korea; Indiana University

Jae Ho Chung, Korea; University of Michigan

Taehyun Kim, Korea; Ohio State University

Jinwoo Choi, Korea; University of Washington

Uk Heo, Korea; University of North Carolina, Chapel Hill

\section{Human Rights: \\ An Answer to President Carter's Challenge}

At the 1989 Annual Meeting, President Carter challenged the Association and its members to do something to protect human rights araund the world. Responding to a question from the audience concerning the disappearance of political scientists in the Middle East, President Carter urged his audience to prevail upon the Association to establish procedures for protesting human rights violations. Unbeknownst to President Carter and, regrettably, the bulk of the audience, the Association has been actively working to protect human rights for several years.

According to the guidelines established in 1982, the Association's Committee on Professional Ethics, Rights and Freedoms will become involved in cases dealing with human rights of scholars in other countries 